\title{
Viruses and acute abdominal pain in childhood
}

\author{
C. R. PUllaN, P. C. HALSE, D. G. SIMS, F. W. AlEXANDER, P. S. GARDNER, \\ AND A. A. CODD \\ Department of Child Health and Public Health Laboratory, Newcastle General Hospital, and \\ Department of Virology, Royal Victoria Infirmary, Newcastle upon Tyne
}

SUMMARY Children aged at least 4 years admitted to hospital with acute abdominal pain, excluding appendicitis, were investigated for the presence of viruses. Out of 181 children 29 were found with viruses of whom 18 had nonspecific abdominal pain. Eight others were found to have virus-like particles on electron microscopical examination of their faeces. Virus infections contribute to a small extent to nonspecific abdominal pain in childhood, but in many cases the cause remains unknown.

In any series of children with acute attacks of abdominal pain worrying enough to require admission to hospital, there is a large proportion (30\% in Jones, $1976 ; 36 \%$ in Sims and Alexander, 1976), in which no cause for the pain is identified. In some of the remaining cases it is possible to demonstrate the presence of a respiratory virus infection.

Kerr et al. (1975) looked at two epidemics of influenza $B$ in Newcastle and found that a high proportion ( $41 \%$ ) of those aged at least 4 years had abdominal pain as a major symptom. Children admitted to this hospital with abdominal pain in 1973 and 1974 were studied retrospectively, identifying some with positive virology (Sims and Alexander, 1976). We decided to look prospectively at admissions of children with acute attacks of abdominal pain to try to ascertain (1) which viruses could be demonstrated, and (2) whether these viruses affected particularly those with unexplained abdominal pain and fever.

\section{Method}

Children aged at least 4 years were entered into

Department of Virology, Royal Victoria Intirmary, Newcastle
upon Tyne
C. R. PULLAN, senior research associate
Newcastle General Hospital
Regional Transfusion Centre
P. C. HALSE, registrar
Department of Child Health
F. W. ALEXANDER, consultant paediatrician
Public Health Laboratory
A. A. CODD, consultant virologist
Oldham General Hospital, Lancashire
D. G. SIMS, senior research associate
Division of Microbiological Reagents and Quality Control,
Central Public Health Laboratory, London
P. S. GARDNER, director

Department of Virology, Royal Victoria Infirmary, Newcastle upon Tyne

Newcastle General Hospital

Regional Transfusion Centre

Public Health Laboratory

A. A. CODD, consultant virologist

OAm General Hospital, Lancas

Division of Microbiological Reagents and Quality Control, P. S. GARDNER, director the study if they were admitted as an emergency complaining of acute abdominal pain between midJuly 1975 and the end of April 1977. Those with acute appendicitis were excluded.

On admission the children had the following investigations: (1) Nasopharyngeal secretions (NPS) for viral diagnosis by the flourescent antibody technique (FAT) and by culture. (2) Nose and throat swabs for viral culture. (3) Stool for viral culture and electron microscopy (EM). (4) Serum for viral antibody titres by complement fixation. Blood samples 10 days later were repeated if possible. (5) Blood for a white cell count and differential. (6) Urine for culture and microscopy. (7) Throat swabs for bacterial culture.

\section{Results}

During the $21 \frac{1}{2}$ months of the study, there were 297 admissions with acute abdominal pain and 85 $(29 \%)$ of these had appendicitis. $181(85 \%)$ of the remaining 212 had some virological screening and were studied further. Most of those who had no specimens taken were admitted and discharged over a weekend. $80(44 \%)$ of the detailed study group were boys and $101(56 \%)$ were girls. Their ages ranged from 4 to 16 years. $123(68 \%)$ had had pain for 2 days or less, and only $22(12 \%)$ had had pain for over 4 days. $37(20 \%)$ had abdominal pain only; $84(46 \%)$ had associated vomiting. $49(27 \%)$ had fever $\geqslant 38^{\circ} \mathrm{C}$ during their admission. There was no clustering of cases or seasonal variation.

The diagnoses are listed in Table 1. Children diagnosed as having nonspecific abdominal pain had acute pain, without any apparent cause, associated sometimes with vomiting and generally lasting for 1-2 days before settling. Those diagnosed as having recurrent abdominal pain had an acute 
episode of pain with a history of a number of similar previous episodes where no cause had been found.

Investigations are listed in Table 2.

We identified 33 viruses in $29(16 \%)$ cases, 18 of

Table 1 Diagnosis made in children admitted with acute abdominal pain, excluding those with appendicitis

\begin{tabular}{llc}
\hline Diagnosis & Children $(n=181)$ & $\%$ \\
\hline Nonspecific abdominal pain & 99 & 55 \\
Upper respiratory tract infection & 28 & 16 \\
Recurrent abdominal pain & 14 & 8 \\
Urinary tract infection & 8 & $4 \cdot 5$ \\
Constipation & 6 & $3 \cdot 3$ \\
Mesenteric adenitis (at laparotomy) & 6 & $3 \cdot 3$ \\
Significant psychological problems & 5 & $2 \cdot 8$ \\
Gastroenteritis & 5 & $2 \cdot 8$ \\
Pneumonia (one pneumococcal) & 3 & \\
Meningitis & 2 & \\
Hepatitis & 2 & \\
Subacute intestinal obstruction; & & \\
torsion of ovary; duodenal ulcer & 1 each \\
\hline
\end{tabular}

Table 2 Investigations performed in 181 cases of acute abdominal pain

\begin{tabular}{lrc}
\hline Investigation & No. & $\%$ \\
\hline Nasopharyngeal secretions & 176 & 98 \\
Nose and throat swabs & 162 & 91 \\
Stool specimen & 94 & 53 \\
Paired sera & 109 & 61 \\
White cell count & 169 & 95 \\
Urine examination & 165 & 93 \\
Throat swab (bacteriology) & 144 & 81 \\
\hline
\end{tabular}

whom had nonspecific abdominal pain (Table 3). Virus-like particles were seen on electron microscopical examination in the faeces of 8 additional children. Four had spherical particles of 19-22 nm with well defined capsids and generally showing hollow forms (Fig. 1). Three had spherical particles of 28-31 nm with well defined capsids, capsomeres

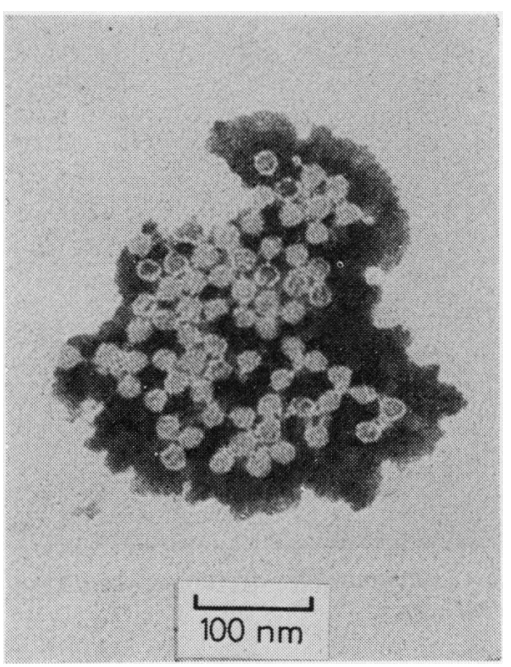

Fig. $1 \quad 19-21 \mathrm{~nm}$ particles agglutinated with patient's convalescent serum.

Table 3 Viruses found in 181 cases of acute abdominal pain

\begin{tabular}{|c|c|c|c|c|c|c|c|}
\hline \multirow[t]{2}{*}{ Clinical diagnosis } & \multirow[t]{2}{*}{ Virus found } & \multirow[t]{2}{*}{ Total } & \multicolumn{5}{|c|}{ Methods of identification } \\
\hline & & & $\begin{array}{l}\text { F.AT } \\
\text { on NPS }\end{array}$ & $\begin{array}{l}\text { Culture of } \\
\text { nose and } \\
\text { throat swab }\end{array}$ & $\begin{array}{l}\text { Culture } \\
\text { stool }\end{array}$ & $E / M$ & $\begin{array}{l}\text { Rising } \\
\text { antibody } \\
\text { titre }\end{array}$ \\
\hline \multirow{13}{*}{$\begin{array}{l}\text { Nonspecific } \\
\text { abdominal pain }\end{array}$} & Influenza $\mathbf{A}$ & 4 & 1 & 1 & & & 4 \\
\hline & Influenza B & $2^{*}$ & 1 & 1 & & & 1 \\
\hline & $\begin{array}{l}\text { Parainfluenza 1 } \\
\text { Mumps }\end{array}$ & $\begin{array}{l}1 \\
1\end{array}$ & & 1 & & & 1 \\
\hline & Echo 30 & 1 & & 1 & & & \\
\hline & Echo 3 & $i$ & & & 1 & & \\
\hline & H-rhino & 2 & & 2 & & & \\
\hline & Herpesvirus & 1 & & 1 & & & \\
\hline & Coxsackie B5 & 2* & & & 2 & & \\
\hline & Coxsackie B6 & 1 & & & 1 & & \\
\hline & Astrovirus & $1^{*}$ & & & & 1 & \\
\hline & Rotavirus & 1 & & & & 1 & \\
\hline & Enterovirus ?type & $2^{* * *}$ & & & & 2 & \\
\hline & Coronavirus & $1^{*}$ & & & & 1 & \\
\hline \multirow{4}{*}{$\begin{array}{l}\text { Upper respiratory } \\
\text { tract symptoms }\end{array}$} & Influenza A & 2 & 2 & & & & 2 \\
\hline & $\begin{array}{l}\text { Influenza B } \\
\text { Parainfluenza 1 }\end{array}$ & $\begin{array}{l}2 \\
1 *\end{array}$ & 2 & & & & \\
\hline & Coxsackie B5 & $1^{*}$ & & & 1 & & \\
\hline & Enterovirus ?type & 1 & & & & 1 & \\
\hline \multirow[t]{2}{*}{ Meningitis } & Echo 30 & 1 & & & 1 & & \\
\hline & Echo 19 (also found in CSF) & $i$ & & 1 & 1 & & \\
\hline Gastroenteritis & Echo 1 & 1 & & & 1 & & \\
\hline Recurrent abdominal pain & Coxsackie B5 & 1 & & & 1 & & \\
\hline Duodenal ulcer & Astrovirus & 1 & & & & 1 & \\
\hline Total & & 33 & 7 & 8 & 9 & 7 & 8 \\
\hline
\end{tabular}

*Two viruses found in one patient. 


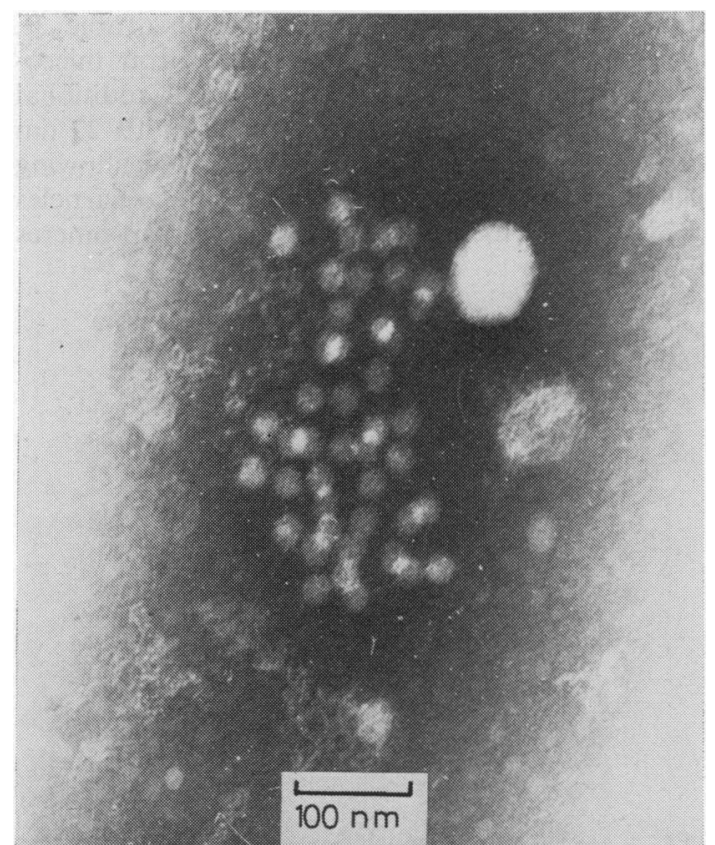

Fig. $2 \quad 28-31 \mathrm{~nm}$ particles agglutinated with patient's convalescent serum.

were very small, and hollow forms were absent (Fig. 2). In one child, both types of particles were seen; 5 of these 8 children had nonspecific pain, 2 had recurrent pain, and one had associated upper respiratory tract symptoms.

Seven $(4 \%)$ of the children had a group $A \beta-$ haemolytic streptococcus grown from the throat swab. Five of these had symptoms of an upper respiratory infection; one had a urinary infection; one had nonspecific abdominal pain and echo 30 in his upper respiratory tract.

$31(17 \%)$ of patients had neutrophil counts of at least $8.0 \times 10^{9} / 1$, and of these, 3 had urinary tract infections and 2 pneumonia. Only 8 had a lymphopenia of $1.5 \times 10^{9} / 1$ or less. There was no correlation between the white cell count and the presence of a virus.

A fever of $38^{\circ} \mathrm{C}$ or above was found in $49(27 \%)$. Of those children with nonspecific abdominal pain, fever was found more often in those in whom a virus was present (6 of 18) than in those in whom a virus was not found (12 of 81). The numbers are small and there is no statistical significance $(\mathrm{P}<0 \cdot 1)$.

\section{Discussion}

Viral infection in childhood seems to play only a small part in the production of abdominal pain.
Viruses are found in asymptomatic children, particularly in faeces (Gamble, 1962; Galbraith, 1965), but also in the upper respiratory tract (Poole and Tobin, 1973; Horn and Yealland, 1974). The present series was not controlled because of the difficulty in obtaining appropriate controls matched for age and season. One would perhaps expect to find a virus in children with symptoms of upper respiratory tract infection, gastroenteritis, or in certain cases of meningitis. Abdominal pain associated with upper respiratory tract symptoms is often called mesenteric adenitis and presumed to be viral.

It is the group with nonspecific pain which is particularly interesting. We found a virus in 18 of 99 children with this diagnosis.

There was not a particularly large epidemic of influenza A or B during the study period or we might well have found a more striking relationship with these viruses. Kerr et al. (1975) noted that there had been an increase in the number of admissions with abdominal pain during the influenza $B$ epidemics of 1973 and 1974.

An increasing number and variety of virus particles is being found in faeces by electron microscopical studies, and some unidentifiable virus-like particles were found in the faeces of the study children. Until more is known about the incidence of these particles in asymptomatic people their significance will remain in doubt.

\section{References}

Galbraith, N. S. (1965). A survey of enterovirus and adenovirus in the faeces of normal children aged $0-4$ years. Journal of Hygiene, 63, 441-455.

Gamble, D. R. (1962). Isolation of Coxsackie viruses from normal children 0-5 years. British Medical Journal, 1, 16-18.

Horn, M. E. C., and Yealland, S. J. (1974). Significance of respiratory virus isolations. Archives of Disease in Childhood, 49, 516-519.

Jones, P. F. (1976). Active observation in management of acute abdominal pain in childhood. British Medical Journal, 2, 551-553.

Kerr, A. A., Downham, M. A. P. S., McQuillin, J., and Gardner, P. S. (1975). Gastric flu. Influenza B causing abdominal symptoms in children. Lancet, 1, 291-295.

Poole, P., and Tobin, J. O'H. (1973). Viral and epidemiological findings in MRC/PHLS surveys of respiratory disease in hospital and general practice. Postgraduate Medical Journal, 49, 778-787.

Sims, D. G., and Alexander, F. W. (1976). Letter: Acute abdominal pain in childhood. British Medical Journal, 2, 880-881.

Correspondence to Dr C. R. Pullan, Department of Virology, Royal Victoria Infirmary, Queen Victoria Road, Newcastle upon Tyne NE1 4LP.

Received 27 February 1979 